Three resinicolous North American species of Mycocaliciales in Europe with a re-evaluation of Chaenothecopsis oregana Rikkinen

\title{
Tuovila, Hanna
}

2012-03

Tuovila , H , Larsson , P \& Rikkinen , J 2012 , ' Three resinicolous North American species of Mycocaliciales in Europe with a re-evaluation of Chaenothecopsis oregana Rikkinen ' , Karstenia , vol. 51 , no. 2 , pp. 37-49 . < http://www.karstenia.fi/51_2_11.php >

http://hdl.handle.net/10138/309667

unspecified

publishedVersion

Downloaded from Helda, University of Helsinki institutional repository.

This is an electronic reprint of the original article.

This reprint may differ from the original in pagination and typographic detail.

Please cite the original version. 


\title{
Three resinicolous North American species of Mycocaliciales in Europe with a re-evaluation of Chaenothecopsis oregana Rikkinen
}

\author{
HANNA TUOVILA, PER LARSSON and JOUKO RIKKINEN
}

\begin{abstract}
TUOVILA, H., LARSSON, P. \& RIKKINEN, J. 2012: Three resinicolous North American species of Mycocaliciales in Europe with a re-evaluation of Chaenothecopsis oregana Rikkinen. - Karstenia 51: 37-49. Helsinki. ISSN 0453-3402.

This study examines what is currently known about the taxonomy, ecology and distribution of three resinicolous Chaenothecopsis species in Europe. A critical re-examination of $C$. oregana revealed that the type material contains two taxa. For nomenclatural reasons the name $C$. oregana is rejected and two new species, $C$. diabolica and $C$. zebrina, are described. Both species occur in western North America and in Europe. Also the European population of $C$. montana is described in detail. All three Chaenothecopsis species mainly live in mature or old-growth forests and can be used as indicators of long forest continuity. Their European distributions, with populations in the northern coniferous forests and in the relict montane forests of Spain and Switzerland, indicate that they may have survived the last glaciation maximum in the same refugia as their host trees.
\end{abstract}

Key words: Mycocaliciales, Chaenothecopsis, taxonomy, resinicolous fungi, biogeography, indicator species

Hanna Tuovila \& Jouko Rikkinen, Department of Biological and Environmental Sciences, University of Helsinki, PO Box 65, FI-00014 Helsinki. Finland; e-mails: hanna. tuovila@helsinki.fi,jouko.rikkinen@helsinki.fi

Per Larsson, Nordiska museet, Julita gård, SE-643 98 Julita, Sweden; e-mail: per.larsson@nordiskamuseet.se

\section{Introduction}

Mycocaliciales Tibell \& Wedin constitutes a well supported group within Ascomycota (e.g. Tibell \& Vinuesa 2005, Geiser et al. 2006). Currently five genera are recognized within the order: Chaenothecopsis Vain., Mycocalicium Vain., Phaeocalicium Schmidt., Stenocybe Nyl. ex Körb. and Sphinctrina Fr., but generic limits within the group are ambiguous and in need of further clarification. Although little is still known about details of substrate ecology, most mycocalicioid fungi are thought to be parasites or parasymbionts of lichens, parasites of freeliving algae, liverworts or vascular plants, or saprotrophs on wood, bark or dead polypores. In addition, some $10 \%$ of the approximately 150 known species grow on conifer resins or other plant exudates. The diversity of the resinicolous species was revised by Tibell and Titov in 1995, but several additional species have since been described from plant exudates (e.g. Rikkinen 2003b, 2003c, Tuovila et al. 2011).

Most presently known species of Mycocaliciales have been found in connection to regional studies on the taxonomy and distribution of calicioid lichens: from Western North America (Rikkinen 1999, 2003a, 2003b, 2003c), Australasia (Tibell 1987) and East Asia (Titov 1998, Titov \& Tibell 1993). As a whole, however, the distri- 
bution and ecology of all Mycocaliciales remain poorly known - partly because comprehensive identification keys are currently lacking. Three species of Mycocalicium and fifteen species of Chaenothecopsis have so far been described from plant exudates. Most of these taxa grow on the resin and/or resin impregnated wood of a single tree species or genus. Although some findings (e.g. Tuovila et al. 2011, Tuovila \& Rikkinen unpubl.) suggest that many resinicolous Chaenothecopsis species grow on angiosperm exudates in the subtropics and tropics, most of the currently known host plants are conifers from temperate and boreal forests of the northern hemisphere, especially species of Abies Mill., Larix Mill., Picea A. Dietr., and Tsuga Carrière (Tibell \& Titov 1995; Titov 2006). All resinicolous species that grow on conifer resins have been described from North America or East Asia.

Three resinicolous species of Mycocaliciales have been reported from Europe: Chaenothecopsis tristis (Körber) Titov on exudates of Acer L. and Tilia L. from three localities in Germany, Italy and Russia (Tibell \& Titov 1999), C. montana Rikkinen on resin of Picea abies (L.) H. Karst. from two localities in Finland (Rikkinen 2003c), and $C$. dolicocephala Titov on resin of $P$. abies from one locality in western Russia (Gudovicheva \& Titov 2007).

Rikkinen (2003c) described Chaenothecopsis oregana Rikkinen as a new species from western North America. Recent studies of the type material have revealed that the original collections from Oregon actually contain two distinct species. Unfortunately, the remaining ascomata in the holotype of $C$. oregana do not correspond to the description of $C$. oregana but instead represent another undescribed species. To resolve this problem the name $C$. oregana will here be rejected and two new species will be described from the same material. Both species occur in western North America and in Europe. Also the currently known distribution of $C$. montana Rikkinen in Europe is mapped. As morphological characters of both new species are consistent with current concept of the genus Chaenothecopsis (Vainio 1927, Schmidt 1970), we place them in this genus pending possible new generic limitations within the family.

\section{Material and methods}

This study is mainly based on field studies and specimens collected mostly by the authors (kept in H, TUR, UPS) in 1997-2011. Different types of conifer forests have been studied, especially in Finland but also in many other parts of Europe, western North America, East Asia, and tropical Africa. Special emphasis has been put on finding and sampling resin flows of conifers in the study sites. Additional specimens are from the herbaria of Helsinki $(\mathrm{H})$, Turku (TUR) and Oulu (OULU) and personal collections of Urs Gröner (Swizerland). The fungal specimens were studied under dissecting and compound microscopes. Anatomical features were observed and measured in water by light microscopy with a $100 \times$ oil-immersion objective. Several reagents were used to observe specific structures: potassium-hydroxide (later K), Lugol's solution (IKI), Melzer's reagent (MLZ), Congo Red (CR), nitric acid $(\mathrm{N})$. Illustrations were drawn from squash mounts with a drawing tubus. The deep fields of focus in habit photographs were achieved by combining several optical sections into composite pictures. As the resinicolous Chaenothecopsis species under study grow exclusively on resin or resin-soaked wood, we do not describe anatomical differences with non-resinicolous species, even though some superficially similar species exist among lichenicolous and lignicolous taxa.

\section{Chaenothecopsis montana Rikkinen - Figs. 1, 5, 7}

Chaenotecopsis montana Rikkinen, Annales Botanici Fennici 40: 446. 2003. - Typus: USA. Oregon. Polk County, Little Sinks Research Natural Area. $44^{\circ} 50.3^{\prime} \mathrm{N}, 123^{\circ} 26.4^{\prime} \mathrm{W}$, on resin and resin-soaked lignum of Abies grandis, alt. 200 m. 1998, Rikkinen 98008 (holotypus, H; isotypi in TUR, UPS, OSC).

Apothecia always on resin or resin-soaked wood of conifers (Picea, Abies, Tsuga). Stipe yellowbrown to black, straight or sometimes curved, rarely branched, $450-1400 \times 50-170 \mu \mathrm{m}(\mathrm{n}=17)$. Capitulum lenticular to hemispheric to subspherical, black to bluish black, $10-40 \times 150-750 \mu \mathrm{m}$ $(\mathrm{n}=17)$. Asci cylindrical, $(34-) 37-50 \times 3.5-5.5$ $\mu \mathrm{m}(\mathrm{n}=20)$, apex 4-8 $\mu \mathrm{m}$ thick, penetrated first by fine, later widening canal, some mature asci without the thickening; hymenium with intense MLZ+ reaction when ascus walls and hyaline, unevenly spread, possibly gelatinous material surrounding the asci turns bright blue; asci with croziers. Ascospores 5.1-7.8 $\times 2.9-4.4(-4.6)$ $\mu \mathrm{m}$, mean $6.5 \times 3.6 \mu \mathrm{m}, \mathrm{Q}=1.3-2.4$, mean $\mathrm{Q}=$ $1.8(\mathrm{n}=144$, from 27 ascocarps, 6 collections), el- 
lipsoid to ovoid, greyish green to brown, smooth. Paraphyses $45-55 \times 1.5-2 \mu \mathrm{m}$, septate, septal intervals $7-10 \mu \mathrm{m}$, branched once or twice in lower part, upper parts crown- or tree-like, forming a $1-3 \mu \mathrm{m}$ thick epithecium, apices swollen, some (10-50 \%) filled with brownish, reflective material. Hypothecium hyaline to greyish green, cells thick-walled. Excipulum well developed, yellow-brown to green, cells ca $6 \mu \mathrm{m}$ wide, wall 1.5-2 $\mu \mathrm{m}$ thick, lumina sometimes filled with dark-coloured pigment, amorphous pigment sometimes accumulated outside the cells. Stipe yellow to greenish brown to green, cells 5-8 $\mu \mathrm{m}$ wide, wall $1.5-3 \mu \mathrm{m}$; hyphae in excipulum and stipe more or less periclinally arranged and slightly intertwined. All parts of apothecium N-, $\mathrm{K}-$, although in the more green ascocarps small amounts of the green colour dissolves into the medium. Some ascocarps display red-orange Kpigments.

Specimens studied (on resin of Picea abies, unless oth erwise stated): FINLAND. Varsinais-Suomi. Vihti, Sipilänmäki, Lintumäki. 6705:3352, 1.X.2008 Tuovila 08-019 (H). Uusimaa. Espoo, Luukki, 6692:3372, 2004 Rikkinen 04001 (H). Sipoo, Hindsby, 66943:34004, 25.VIII.2009 Tuovila 09-173 (TUR). Satakunta. Kankaanpää, Veneskoski. Kiimahohka, 19.8.1935 Kari (TUR, as Mycocalicium subtile). Etelä-Häme, Lammi, Evo, 6794:3396, 18.IX.2007 Tuovila 07-086 (H). Etelä-Savo. Punkaharju, Pitkänahonmäki, 68323:36418, 22.IX.2009 Tuovila 09224 (TUR). Laatokan Karjala, Parikkala, Oronmylly, 68369:36361, 22.IX.2009 Tuovila 09-232 (TUR). Parikkala, Soininmäki, 6835602:3623466, 16.IX.2009 Rämä 559/09a (OULU). Pohjois-Häme. Juupajoki, Hyytiälä, 68628:33573, 1999 Rikkinen 201500 (H). Saarijärvi, Pyhä-Häkki, National Park, 697:342, 1999 Rikkinen 201502 (H); Kulha forest reserve, Syväojanrotko, 69438:33956, 1999 Rikkinen 201501 (H). NORWAY. Akershus. Enebakk, Vangen, 59 49' 7'N, $11^{\circ} 0$ ' 1'"E, V 2010. Larsson, 2 specimens. Frogn Frydenlund $59^{\circ} 42^{\prime} 25^{\prime} \mathrm{N}, 10^{\circ}$ 44' 2"E, VII 2010 Larsson. Frogn, tunnel at the end of the road 23, $59^{\circ} 42^{\prime} 27^{\prime \prime} \mathrm{N}, 10^{\circ} 43^{\prime} 43^{\prime \prime} \mathrm{E}, 25$.VII.2010 Larsson. Ski, Kollåsen, 59 $45^{\circ} 10^{\prime \prime} \mathrm{N}, 10^{\circ} 57^{\prime} 30^{\prime \prime} \mathrm{E}$, 29.VIII.2010 Larsson, 2 specimens. Ås, Bjerklund 59 40' 55' $\mathrm{N}, 10^{\circ} 45^{\prime}$ 48”'E, 8.IX.2010 Larsson, 3 specimens. Oslo, Østmarksetra. $59^{\circ} 53.4^{\prime} \mathrm{N}, 10^{\circ} 52.1^{\prime} \mathrm{E}, 14 . \mathrm{XI} .2009$ Tuovila 09-249 (TUR), 09-250 (H). Hordaland. Flatanger, Stordalen $64^{\circ} 26.5^{\prime} \mathrm{N}, 10^{\circ} 57.8^{\prime} \mathrm{E}$, 4.IX.2009 Tuovila 09-191(O), 09-193 (TUR). Nord-Trøndelag. Steinkjer, Kvam, Noem, $64^{\circ} 10.2^{\prime} \mathrm{N}, 11^{\circ} 48.5^{\prime} \mathrm{E}, 2 . \mathrm{IX}$. 2009 Tuovila 09-184 (H). SPAIN. Málaga. Estepona, Paraje Natural Los Reales de Sierra Bermejar. $36^{\circ} 29^{\prime} 29^{\prime} \mathrm{N}, 5^{\circ} 12^{\prime}$ 08 "W, alt. $1120 \mathrm{~m}$., on resin and resin-soaked wood of Abies pinsapo, 26.II.2011 Rikkinen 110096. SWEDEN. Gotland. Alskog kommun, Ollajvs Nature reserve, $57^{\circ}$ 20.2'N, $18^{\circ} 41.3^{\prime}$ E, 27.IX.2011 Tuovila 11-016 (H). Uppland. Lohärad, Ladängen, $59^{\circ} 51^{\prime} 59^{\prime}$ 'N $18^{\circ} 29^{\prime} 28^{\prime \prime} \mathrm{E}$, 17.IV 2010 Larsson 157. SWITZERLAND. Schwyz.
Muothal, Walkarstrücken N, Mittlist Weid, 58' $38^{\prime}$ N, $03^{\circ} 48^{\prime} 38^{\prime \prime} \mathrm{E}, 46^{\circ}$, alt. $1360 \mathrm{~m}$., on resin and resin-soaked wood of Abies alba, 12.XI.2003 Gröner 2783. USA. California. Trinity County, Scott Mountain. $41^{\circ} 15.4^{\prime} \mathrm{N}, 122^{\circ}$ $62.1^{\prime} \mathrm{W}$, alt. $1000 \mathrm{~m}$, on resin and resin-soaked lignum of Abies sp. 1997 Rikkinen 97052 (H). Oregon. Benton County, MacDonald Research Forest, $44^{\circ} 38.47^{\prime} \mathrm{N}, 123^{\circ}$ $18.79^{\prime} \mathrm{W}$, alt. $180 \mathrm{~m}$. on resin and resin-soaked lignum of Abies grandis, amongst C. diabolica, 1998 Rikkinen 98363 (TUR). - Washington. Skamania County, Thorton T. Munger Research Natural Area, $45^{\circ} 49^{\prime} \mathrm{N}, 121^{\circ} 58^{\prime} \mathrm{W}$, alt. 350 m, 1998 Rikkinen $98499(\mathrm{H})$.

Chaenothecopsis montana is characterized by its peculiar paraphyses and the strongly thickened ascus tip. C. tsugae Rikkinen also has relatively thick ascus tips and aseptate, similarly-sized to slightly larger spores. However, the spores of C. tsugae are cylindrical, not ellipsoid or ovoid and the paraphyses are branched only once or twice and without strongly pigmented tips, distinguishing it from C. montana. Also, the stipe of $C$. tsugae is grey, not brownish to black like in C. montana.

Microscopically C. montana shares several characteristic features with Mycocalicium sequoiae Bonar and C. nigripunctata Rikkinen. All three species have strongly thickened ascus tips, paraphyses with tree-like branching, and a strong amyloid reaction of the hymenium. $M$. sequoiae lacks the gelatinous material in hymenium and the paraphyse tips are more round and swollen and only rarely thickened, never pigmented. $C$. nigripunctata has distinctively larger spores (ca $15 \mu \mathrm{m})$ and slender paraphyses. Macroscopically all three species are very distinctive and easy to tell apart: $M$. sequoiae has bright sulphur-yellow pruina on the apotechium, $C$. nigripunctata has grey apothecium with spores masses appearing as black spots on top of the epithecium. Despite macroscopical differences, in DNA analyses these three species have consistently grouped together and formed a well supported clade (Tuovila \& Rikkinen unpubl.).

All our C. montana specimens from western North America have been yellowish brown, only rarely with green shades in the excipulum. The European specimens have usually had green excipulum and brown, or rarely green stipe. There are minor differences in hyphal pigments and other features between North American and European specimens, but these are not considered to justify the recognition of different species. 


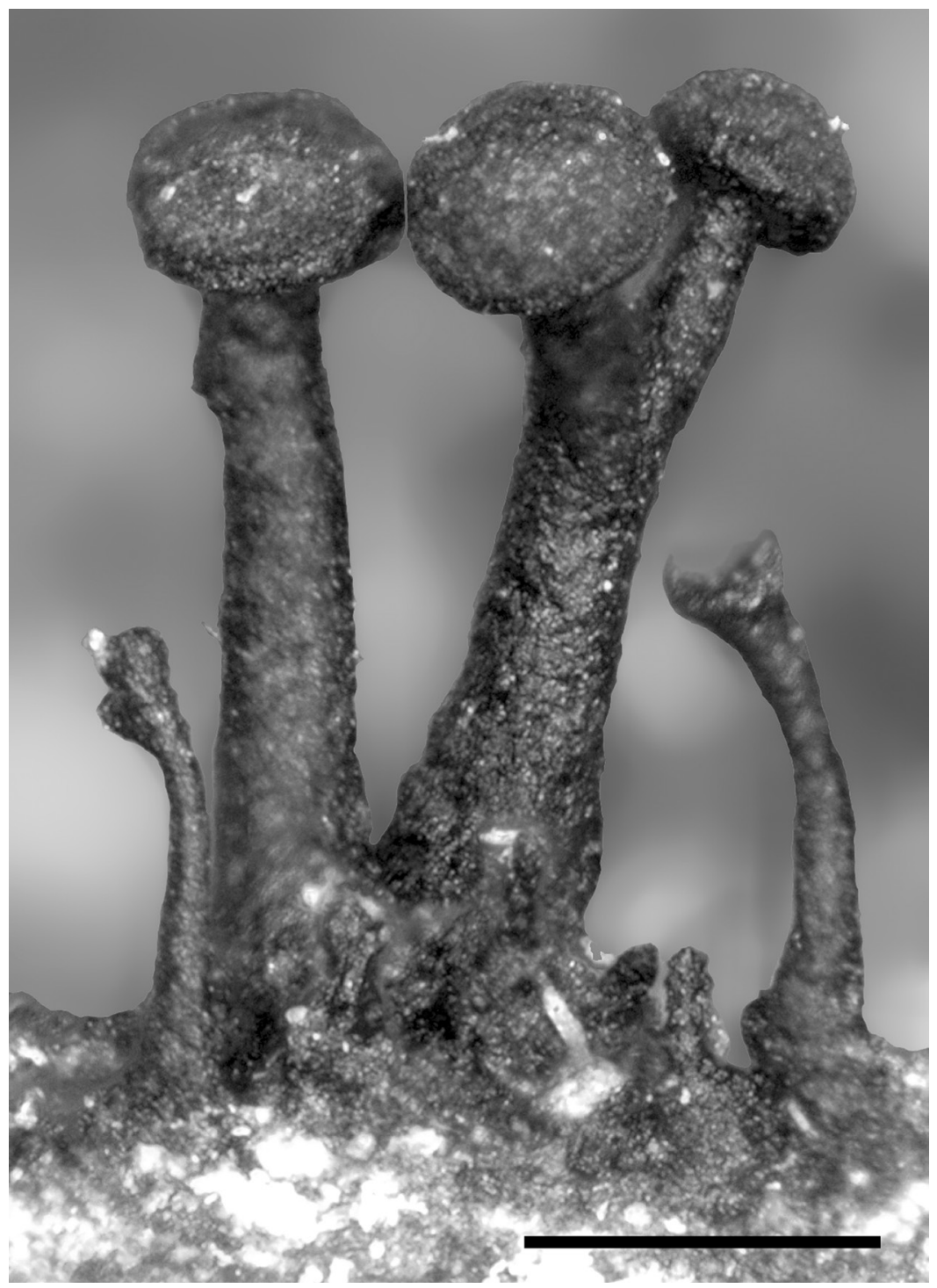

Fig. 1. Ascomata of Chaenothecopsis montana (Rikkinen 98008). Bar $=500 \mu \mathrm{m}$. Photo: J. Rikkinen.

\section{Chaenothecopsis diabolica Rikkinen \&} Tuovila, sp. nova - Figs. $2-3,5,8$ MycoBank no.: MB564001

Ascomata supra exudatum arborum coniferarum, nigra, epruinosa. Stipes rectus vel flexuosus, saepe ramosus, lucens, 300-1000 × 40-120 $\mathrm{mm}$. Capitula lenticularia vel subsphaerica, 70-120 $\times 120-160 \mu \mathrm{m}$. Excipulum et stipes hyphis periclinater ordinatis sed irregularibus, partim con- textis, flavo-brunnae vel viridi-brunnae. Asci cylindrici, 50-70 × 3-5 $\mu \mathrm{m}$. Ascosporae aseptatae, ellipsoideae vel fusiformes, brunneae, cum ornamento distincto vel minuto, (6.8-)6.9-9.8(-10.2) $\times 3.0-4.6(-5.2) \mu \mathrm{m}$.

Typus: USA. Oregon. Benton County, McDonald Research Forest, between Sulphur Springs trailhead and Forest Service Road 800, 44. $0^{\circ}$ $38.47^{\prime} \mathrm{N}, 123^{\circ} 18.79^{\prime} \mathrm{W}$, alt. $185 \mathrm{~m}$, on resin and 
resin-soaked lignum of Abies grandis, 1998 Rikkinen 98363 (holotypus H, isotypus TUR).

Etymology: diabolica refers to the demonic way this species was able to confuse and hide within the material of $C$. zebrina for years.

Apothecia always on resin and resin-soaked wood of conifers. Stipe slender, black, shiny, straight or flexuous, often branched, 300-1000 $\times 40-120 \mu \mathrm{m}(\mathrm{n}=13)$; new apothecia, often several, proliferate from an old capitulum. Capitulum black, 70-120 × 120-160 $\mu \mathrm{m}(\mathrm{n}=13)$. Asci formed with croziers, cylindrical, 50-70 × 3-5 $\mu \mathrm{m}(\mathrm{n}=11)$, apex variously thickened, often penetrated by a short canal, mature asci sometimes without thickening, hymenium IKI + , reaction fast and can be observed only by adding fresh IKI to a partly dried water squash preparation while observing through the microscope, the blue reaction usually disappears in seconds after the IKI has penetrated the material. Ascospores (6.8-) 6.9-9.8 $(-10.2) \times 3-4.6(-5.2) \mu \mathrm{m}$, mean $8.1 \times$ $4.0 \mu \mathrm{m}, \mathrm{Q}=1.5-2.8$, mean $\mathrm{Q}=2.1(\mathrm{n}=119$, from 14 ascocarps, 5 collections), ellipsoid to fusoid, aseptate, brown; in mature, dispersed spores, cell wall thickened at spore ends and spores usually ornamented with irregular to sigmoid-shaped low ridges parallel to, or slightly angled from the long axis of spore, ornamentation barely noticeable to rough; all ascocarps with varying proportion of smooth spores; spore ornamentation seems to develop late and so the proportion of ornamented spores and degree of ornamentation most likely depends on the age of the ascocarp. Paraphyses 50-60 × 1.6-1.8 $\mu \mathrm{m}$, straight, branched usually twice, septate, septal intervals 6-14 $\mu \mathrm{m}$; in ageing ascocarps paraphyses grow through the epithecium and appear as hyaline hair-like structures on top of the epithecium under 50× magnification. Excipulum well developed, brown, hyphae 3-7 $\mu \mathrm{m}$ wide, cell wall $1-1.5 \mu \mathrm{m}$; especially in the upper part of the excipulum hyphae uneven and angular, but more or less parallel; in the lower parts of excipulum and upper part of stipe hyphae strongly intertwined, making the structure a mosaic of more or less cubical cells. Hypothecium pale greyish brown.

Stipe yellowish or greenish brown to brown, hyphae $3.5-13 \mu \mathrm{m}$ wide, cell wall $1.5-2 \mu \mathrm{m}$, excluding the upper part, hyphae in parallel arrangement, only slightly intertwined; in the basal part cells large, irregular, with very thick walls, even up to $8 \mu \mathrm{m}$, wall possibly two-layered, with layer closest to the lumina (width $25 \%$ of the cell wall) reflecting light differently from the rest of the wall; thick-walled cells are red in fresh IKI; red colour can be observed in IKI in inner layer of the cell wall, sometimes also in the outer layer; sometimes all thick-walled parts of stipe IKI+ (red), reaction developing slowly, not instantly. Epithecium formed of sparse net of 4-5.5 $\mu \mathrm{m}$ wide hyphae; the hyphal net also covers the excipulum and stipe.

Specimens studied: SPAIN. Málaga. Estepona, Paraje Natural Los Reales de Sierra Bermeja, 36² $29^{\prime} 29.5^{\prime}$ N, $5^{\circ}$ 12'08.3'W, alt. $1120 \mathrm{~m}$, on resin and resin-soaked wood of Abies pinsapo, 26.II.2011 Rikkinen 110096 (H). USA. Oregon. Benton County, McDonald Research Forest, Oak Creek, $44^{\circ} 36.2^{\prime} \mathrm{N}, 123^{\circ} 20.1^{\prime} \mathrm{W}$, alt. 150 m, 1998 Rikkinen $98418(\mathrm{H})$. Curry county, Port Orford Heads State Park, $42^{\circ} 44.2^{\prime} \mathrm{N} 124^{\circ} 30.5^{\prime}$ W, alt. 65 m, 1.X.2006 Tuovila 06-035 (H). Polk County, Little Sinks Research Natural Area, 44 $50.3^{\prime} \mathrm{N}, 123^{\circ} 26.4^{\prime} \mathrm{W}$, alt. $200 \mathrm{~m}$, on resin and resin-soaked lignum of Abies grandis, amongst C. montana, 1998 Rikkinen 98008 (TUR).

Chaenothecopsis diabolica is distinguished from other species of Mycocaliciales on conifer resin by its characteristic ascospores. Spore size, the distinctive ornamentation of mature spores, and the thickened walls of spore ends distinguish it from all other species with one-celled spores on conifer resin (C. resinicola Tibell \& Titov, C. tsugae, and M. sequoiae). C. resinicola has smaller and smooth spores, while $C$. tsugae is a significantly larger species (ascocarps 1.5-4 $\mathrm{mm}$ high), and has a very different stipe structure and smooth, cylindrical spores. M. sequoiae has ascomata arising from stromata, branching paraphyses and a different ascus tip structure and wider spores. C. khayensis Rikkinen \& Tuovila and several other undescribed species from angiosperm exudates (Tuovila et al. 2011, Tuovila \& Rikkinen, unpubl.) have a similar kind of IKI+ red reaction in thick-walled hyphae of the stipe, but they differ in many other morphological features, and in substrate ecology. 
Chaenotheopsis zebrina Rikkinen \& $\begin{array}{ll}\text { Tuovila, sp. nova } & - \text { Figs. 4-6 } \\ \text { MycoBank no.: MB564002 }\end{array}$

Supra exudatum arborum coniferarum. Ascomata nigra, epruinosa. Stipes rectus vel flexuosus, interdum ramosus, lucens, 270-1000 × 30-800 $\mu \mathrm{m}$. Capitula lenticularia vel subsphaerica, 70 $230 \times 110-320 \mu \mathrm{m}$. Excipulum et stipes hyphis periclinater ordinatis, vinoso-brunnae vel vinoso-rubrae. Asci cylindrici, 40-55.5×3-3.5 $\mu \mathrm{m}$. Ascosporae aseptatae, ellipsoideae vel cylindricae, rubro-brunneae, leves, (4.2-)4.8-6.3(-6.8) $\times(1.8-) 2.1-3.2 \mu \mathrm{m}$.

Typus: USA. Oregon. Polk County, Little Sinks Research Natural Area. $44^{\circ} 50.3^{\prime} \mathrm{N}, 123^{\circ} 26.4^{\prime} \mathrm{W}$, alt. $200 \mathrm{~m}$, on resin and resin-soaked lignum of Abies grandis, 1998 Rikkinen 98010 a (holotypus $\mathrm{H}$, isotypi TUR, OSC).

Etymology: The epithet refers to the zebra-like microscopic alterations of dark and light colours of the ascocarp.

Apothecia always on resin and resin-soaked wood of conifers. Stipe slender, straight, or more infrequently flexuous, sometimes branched or proliferated, shiny, 270-1000 × 30-800 $\mu \mathrm{m}$ $(\mathrm{n}=18)$. Capitulum lenticular to subspheric, black, $70-230 \times 110-320 \mu \mathrm{m} \quad(\mathrm{n}=18) . \quad$ Asci formed with croziers, cylindrical, 40-55.5 $\times$ 3-3.5 $\mu \mathrm{m}(\mathrm{n}=13)$, apex variously thickened, usually penetrated by a canal, mature asci mostly without thickening, hymenium IKI + , reaction fast and can be observed only by adding fresh IKI to a partly dried water squash preparation while observing through the microscope, the blue reaction usually disappears in seconds after the IKI has penetrated the material. Ascospores (4.2)4.8-6.3(-6.8) × (1.8-)2.1-3.2 $\mu \mathrm{m}$, mean $5.6 \times$ 2.7, $\mathrm{Q}=1.6-2.8(-3.0)$, mean $\mathrm{Q}=2.1(\mathrm{n}=134,18$ ascocarps, 6 collections), ellipsoid to cylindrical, smooth, aseptate, reddish brown. Paraphyses 45-65 $\times 1.3-1.5 \mu \mathrm{m}$, straight, branched once or twice, septate, septal intervalls 3-6.5 $\mu \mathrm{m}$; at the ascus tip level paraphyses curve and partly cover and surround ascus tips below epithecium. Excipulum and stipe with similar structure: walls and septae unevenly thickened and strongly wine-red or wine-brown, more or less parallel and only in places slightly intertwined, hyphae in stipe $4-5$ $\mu \mathrm{m}$ wide, in excipulum 3-4 $\mu \mathrm{m}$ wide, walls 1.5 $2 \mu \mathrm{m}$, thick-walled hyphae continue also to form a very solid and tight epithecium above the asci. All outer parts of ascocarp IKI+ (red). The colour reaction can be difficult to observe due to the strong colour of hyphae, but is rather easily seen in more hyaline or lightly coloured parts. $H y$ pothecium light wine-red to greyish red. Small red pigment crystals present in most mature ascocarps, young ascocarps usually without, they do not dissolve in $\mathrm{K}$, but the wine-red colours of hyphae intensify to more purplish red.

Chaenothecopsis zebrina is characterized by the wine-red-brownish coloured structure of stipe and excipulum. The conspicuous contrast between light reflecting cell lumina and dark cell walls give the stipe the appearance of zebra stripes under the microscope. The red pigment crystals are usually, but not always, present. Of the other Chaenothecopsis species on conifer resin, C. zebrina most resembles $C$. resinicola. The ascospores of both species are very similar, only slightly larger in C. zebrina. However, the hyphal structure of the stipe is very different. $C$. resinicola has anticlinally oriented and more or less intertwined hypha. The very solid structure of epitechium and the IKI+ (red) reaction of the whole ascocarp combined to the overall habit are also good characters for identifying the species. We have not had the opportunity to study the type material of Mycocalicium chaudhari Tewari \& Pant, but based on the photographs in Tibell \& Titov (1995) the structure of the stipe and excipulum in this species somewhat resembles that of C. zebrina. However, M. chaudhari is a tropical species described from exudate of Mangifera indica L. and has very different ascospores and asci.

Specimens studied: SPAIN. Málaga. Estepona, Paraje Natural Los Reales de Sierra Bermeja. 36 29' 29.5'N, $5^{\circ}$ $12^{\prime} 08.3$ " W, alt. $1120 \mathrm{~m}$, on resin and resin-soaked wood of Abies pinsapo, 26.II.2011 Rikkinen 110096 (H). SWEDEN. Gotland. Alskog kommun, Ollajvs Nature reserve and Natura 2000 area. $57^{\circ} 20.2^{\prime} \mathrm{N}, 18^{\circ} 41.3^{\prime} \mathrm{E}$, on resin of Picea abies. 27.IX.2011, Tuovila 11-017. Uppland. Lohärad, Ladängen. $59^{\circ} 51^{\prime} 59^{\prime} \mathrm{N}, 18^{\circ} 29^{\prime} 28.0^{\prime \prime} \mathrm{E}$, on resin of Picea abies, 17.IV 2010 Larsson 158. SWITZERLAND. Schwyz. Muothal, Walkarstrücken N Mittlist Weid, $46^{\circ} 58^{\prime} 38^{\prime \prime} \mathrm{N}, 03^{\circ} 48^{\prime} 38^{\prime \prime}$, alt. $1360 \mathrm{~m}$, on resin and resin-soaked wood of Abies alba, 12.XI.2003, Gröner 2783. USA. Oregon. Lincoln County, H.B. Van Duzer Forest Corridor Wayside, $45^{\circ} 02.2^{\prime} \mathrm{N}, 123^{\circ} 48.6^{\prime} \mathrm{W}$, alt. $150 \mathrm{~m}$, on resin and resin-soaked wood of Tsuga heterophylla, 1998 Rikkinen 98333 (H). Polk County, Little 

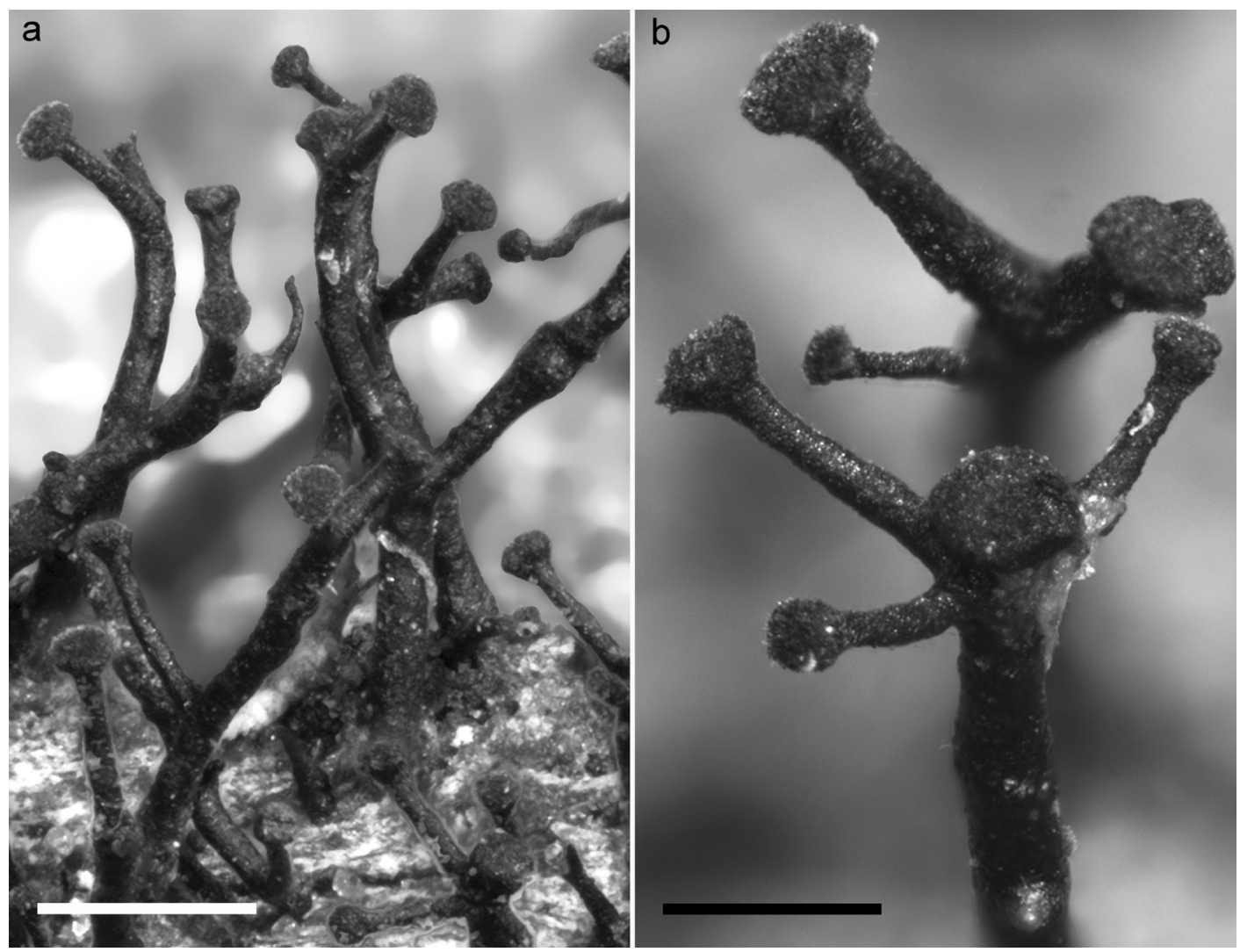

Figs. 2-3. Chaenothecopsis diabolica (Rikkinen 98363). a = ascomata on resin-impregnated wood, bar $=200 \mu \mathrm{m}$; $\mathrm{b}=$ braching ascomata, bar $=50 \mu \mathrm{m}$. - Photo: J. Rikkinen

Sinks Research Natural Area. $44^{\circ} 50.3^{\prime} \mathrm{N}, 123^{\circ} 26.4^{\prime} \mathrm{W}$, alt. $200 \mathrm{~m}$, on resin and resin-soaked lignum of Abies grandis, 1998 Rikkinen $98010 b(\mathrm{H})$.

\section{Discussion}

Four resinicolous species of Mycocaliciales growing on conifer resin have to date been found in Europe. The number of resinicolous species in Western North America is much higher. In addition to the species discussed here, Chaenothecopsis sitchensis Rikkinen, C. tsugae, C. nigripunctata, C. edbergi Selva \& Tibell, and Mycocalicium sequoiae also have been reported. This difference in diversity of resinicolous Mycocaliciales is probably explained by the substantial difference in the diversity of potential host species (Rikkinen 2003a). When compared to Northern Europe, the Pacific coast of North America has a much higher diversity of conifers. In northern Europe Picea abies is the only native conifer that often produces substantial amounts of resin. In Central Europe Abies species can also produce enough resin to support resinicolous Chaenothecopsis species.

Chaenothecopsis montana has so far been collected from Abies alba Mill., A. amabilis Douglas ex J.Forbes, $A$. grandis (Douglas ex D.Don) Lindl., A. pinsapo Boiss., an unidentified Abies species, Picea abies, and Tsuga heterophylla (Raf.) Sarg. C. diabolica has so far been collected from $A$. grandis and $A$. pinsapo, and $C$. zebrina from A. alba and P. abies. Also C. dolicocephala has been reported from resin of both Abies and Picea (Gudovicheva \& Titov 2007). 


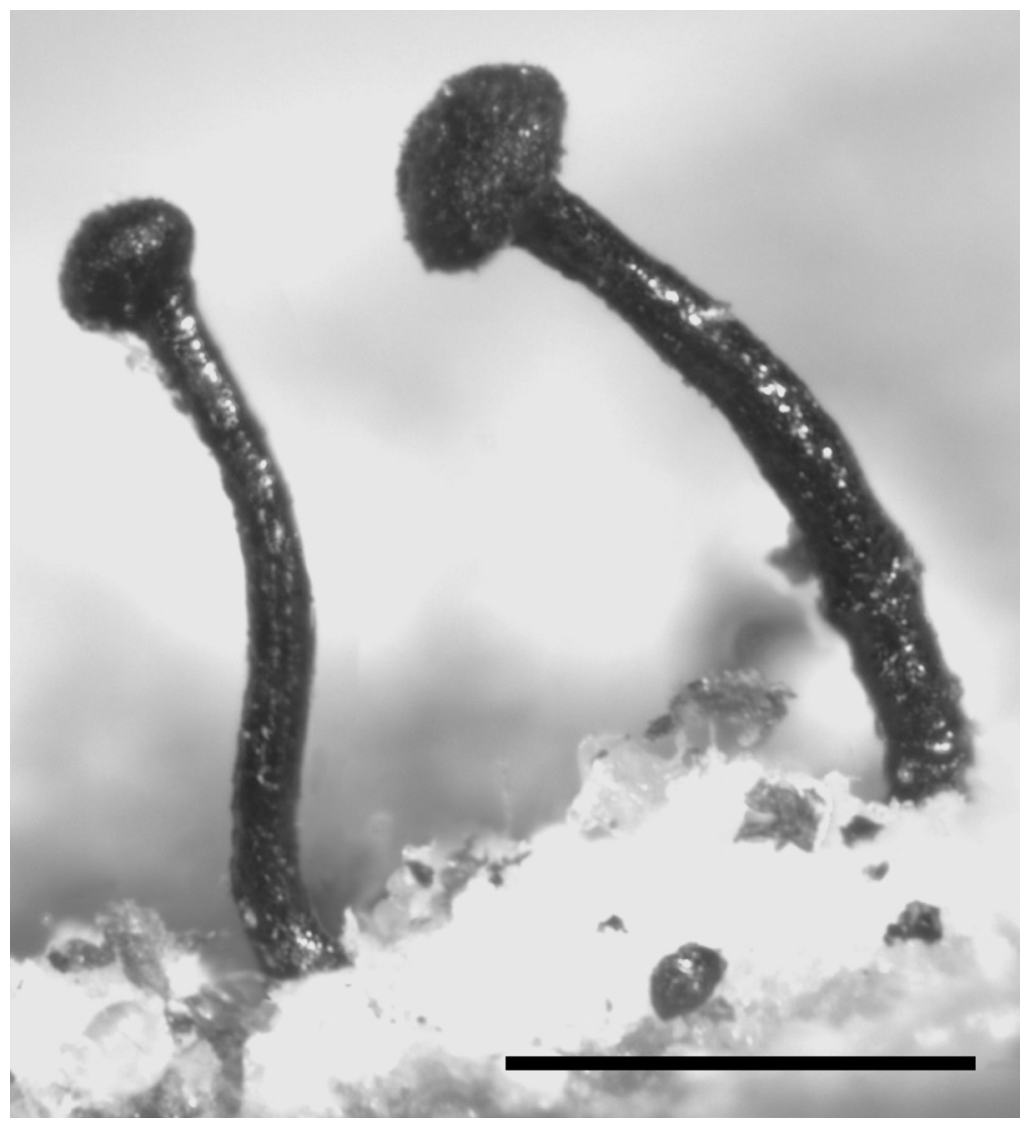

Fig. 4. Ascomata of Chaenothecopsis zebrina (Rikkinen 98333). Bar $=200 \mu \mathrm{m}$.

Photo: J. Rikkinen

Thus, the Chaenothecopsis species on conifer resin do not seem to be as host specific as related fungi on hardwood exudates, like C. khayensis and C. schefflerae (Samuels \& Buchanan) Tibell. One may presume that several additional species of Abies, Tsuga and Picea are among their potential hosts, and possibly also additional conifers from other genera of the Pinaceae. It is interesting that none of the European species of resinicolous Chaenothecopsis have been found from pine resin. This might be linked to the differences in chemical characteristics of pine and spruce resins, but also to the fact that pine resin is rarely in abundant supply in the shaded and moist forest types that resinicolous Chaenothecopsis species prefer.

Chaenothecopsis montana has usually been found growing on relatively soft resin. In three of five collections of C. zebrina, this species grew mixed with $C$. montana, the former species on older, more hardened resin and the latter species on more recent, soft resin. A similar observation was previously reported from North America, then mainly regarding mixed collections of $C$. diabolica (as C. oregana) and C. montana (Rikkinen 2003c).

In Europe resinicolous Chaenothecopsis species have not been found from managed plantations or parks, even if such forests have had conifers with large resinous wounds. All collections from relatively continental regions have been made from mature or old-growth stands and often from virgin forests. In western and coastal Norway the habitat requirements of $C$. montana may be less narrowly restricted. However, also there the most abundant populations have been found from a boreal coniferous rain forest in Stordalen, Flatanger. This unique forest supporst a high di- 


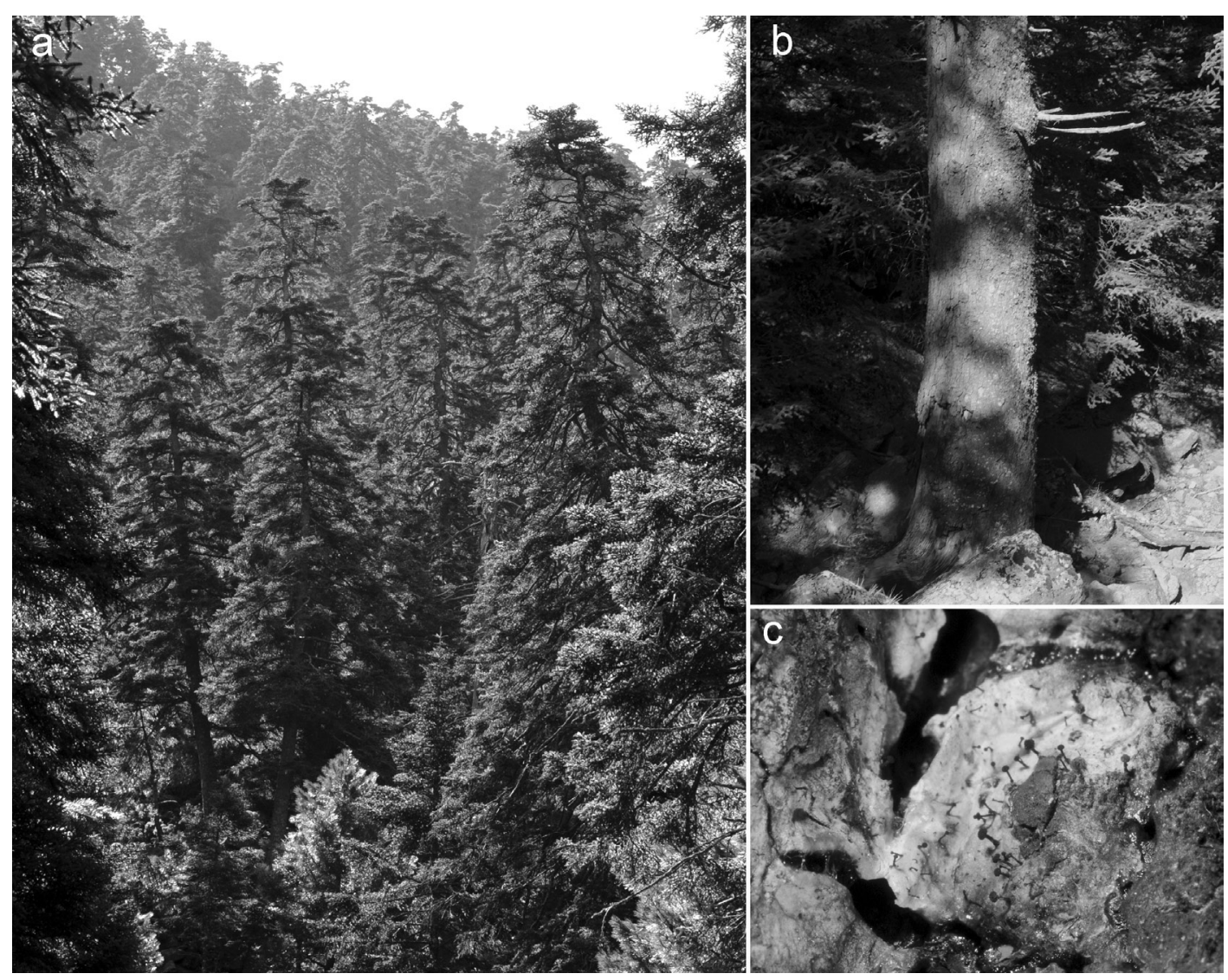

Fig. 5. Habitat of Chaenothecopsis diabolica, C. zebrina and C. montana in Paraje Natural Los Reales de Sierra Bermejar, southern Spain. $\mathrm{a}=$ old-growth Abies pinsapo forest; $\mathrm{b}=$ host tree by a seasonal brook; $\mathrm{c}=$ ascomata on semisolid resin. - Photos: J. Rikkinen

versity of demanding epiphytic lichen species and represents the most oceanic natural habitat of Picea abies in Europe (Hålien \& Tønsberg 1996).

The two collections from Central Europe also originate from special forest types. The Swiss specimens (Gröner 2783) were collected from the high montane zone of the Northern Prealps, from an Abieti-Fagetum forest dominated by $\mathrm{Pi}$ cea abies. The host tree Abies alba is native to this forest which has suffered only limited if any human impact. The Spanish site, a relict Abies pinsapo forest, is also special. Here all three Chaenothecopsis species were collected growing on the resin of one single host tree growing by a seasonal brook (Fig. 5). These isolated findings clearly indicate that also other relict Abies forests in central and southern Europe may house local populations of resinicolous Chaenothecopsis species.

While all three Chaenothecopsis species may still be relatively common in the remaining old growth coniferous forests of western North-America (Rikkinen 2003a, c), their status in Europe is obviously different. Several species of Mycocaliciales are listed as endangered in all Nordic countries (e.g. Thor et al. 2010). C. montana has previously only been known from Finland, where it is presently listed as a category NT species (Jääskeläinen et al. 2010). While it probably is quite rare and possibly endangered, more local populations could be found as general awareness of it and other resinicolous Chaenothecopsis species increases. Even enthusiastic mycologists are not likely to come across 

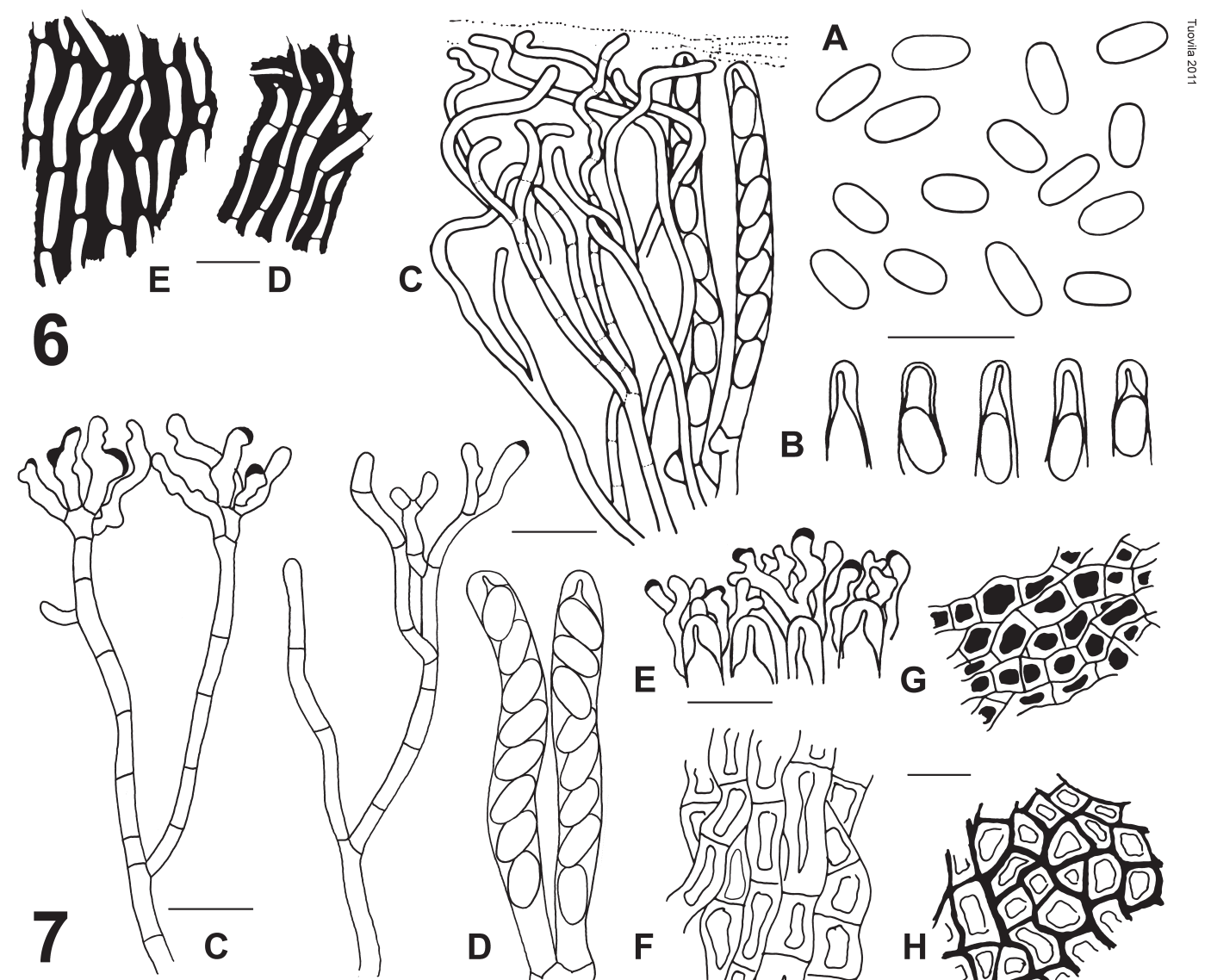

- RAABA
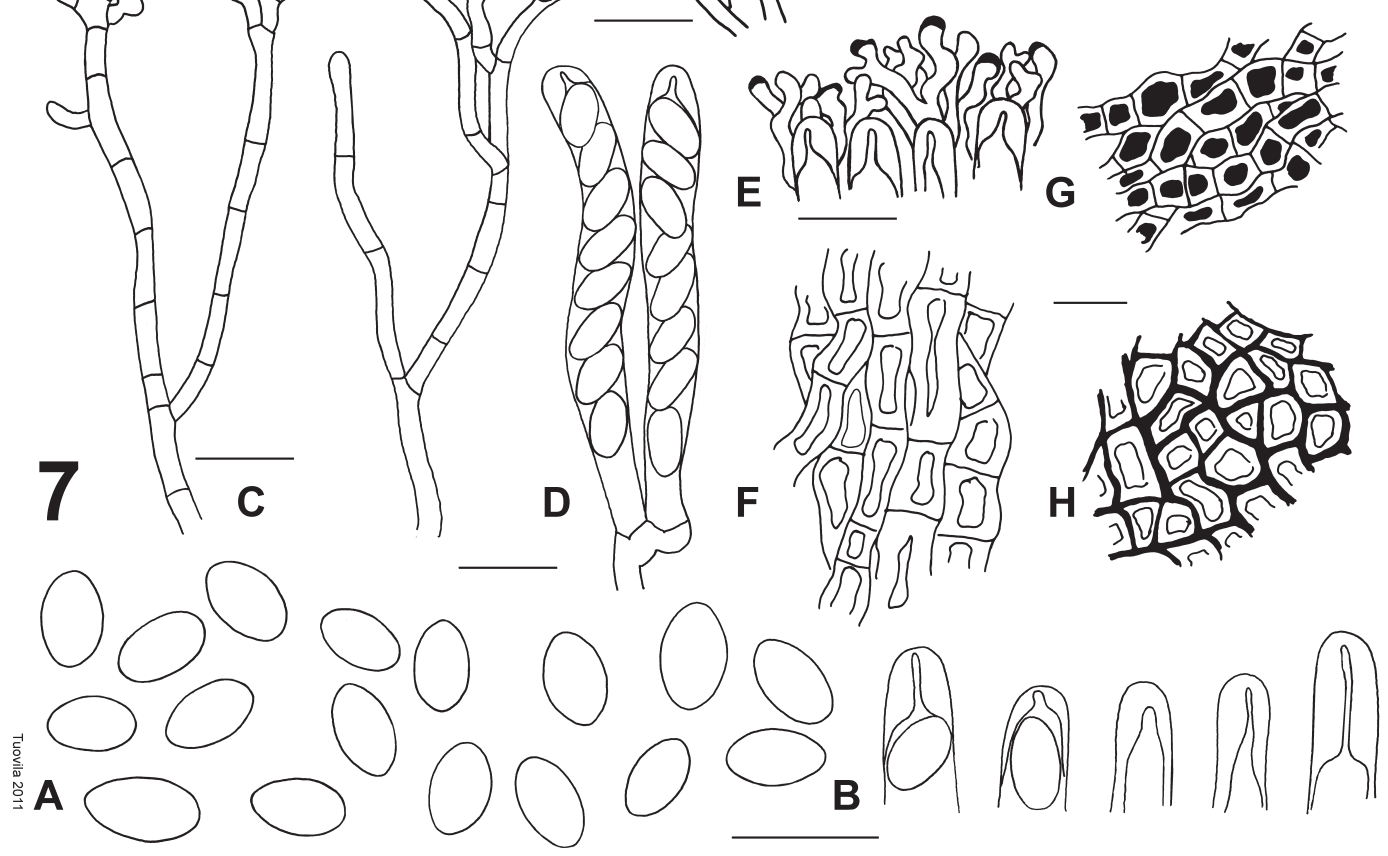

Figs. 6-7. Chaenothecopsis species. Fig. 6. C. zebrina (A, D, E = Rikkinen 98010a, A =110096, A-C = Gröner 2783), $\mathrm{A}=$ spores from the 3 collections, $\mathrm{B}=$ variation of ascus tips, $\mathrm{C}=$ paraphyses and asci; epithecium and septa in paraphyses indicated with dotted lines, $\mathrm{D}=$ hyphae in excipulum, $\mathrm{E}=$ hyphae in stipe. - Fig 7 . C. montana $(\mathrm{A}-\mathrm{C}, \mathrm{E}-\mathrm{H}=$ Rikkinen 98008, A = 110096, A, B, D = Tuovila 07-086), A = spores from the 3 collections, $\mathrm{B}=$ variation of ascus tips, $\mathrm{C}=$ paraphyses, $\mathrm{D}=$ asci, $\mathrm{E}=$ epithecium formed with tips of paraphyses, $\mathrm{F}=$ hyphae in stipe, $\mathrm{G} \& \mathrm{H}=\mathrm{variation}$ of hyphae in excipulum. Bars $10 \mu \mathrm{m}$. 


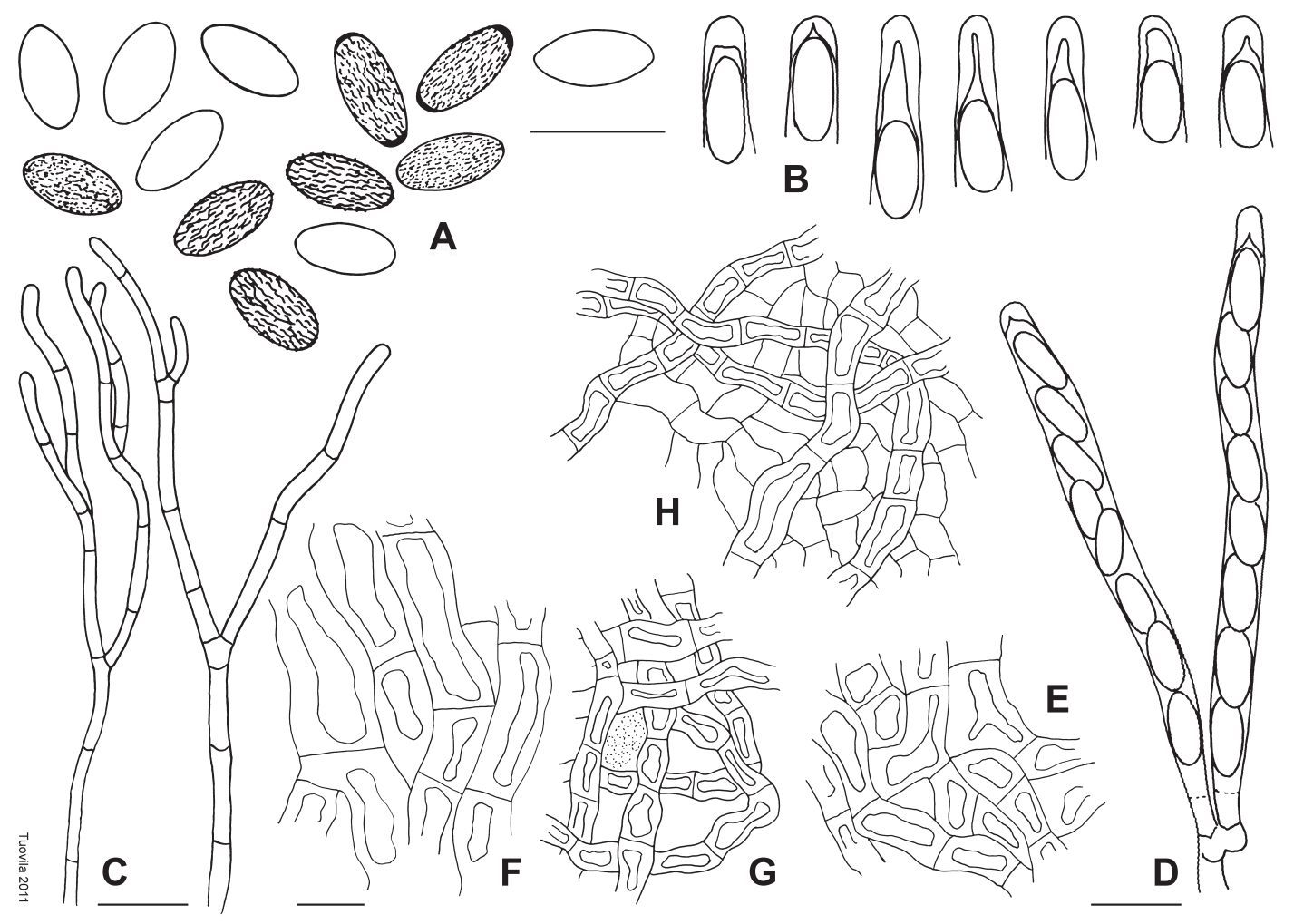

Fig. 8. Chaenothecopsis diabolica (A-C, F-E =Rikkinen 98363, H, A =98418, A, B, D = Rikkinen 110096), A=spores, $\mathrm{B}=$ variation of ascus tips, $\mathrm{C}=$ paraphyses, $\mathrm{D}=$ asci, $\mathrm{E}=$ hyphae in excipulum, $\mathrm{F}=$ hyphae in stipe, $\mathrm{G}=$ epithecium formed of loose net of hyphae, paraphyse apices indicated with dotted lines, $\mathrm{H}=$ overall structure of ascomata with irregular hyphae and loose net of surface hyphae. Bars $10 \mu \mathrm{m}$.

these species by accident, as one really has to search for them in potentially suitable habitats. Especially C. zebrina and C. diabolica, both of which are minute fungi, are difficult to spot without the help of a hand lens. A search for C. montana has often been productive if the strict habitat requirements (old, moist spruce forest with damaged trunks, preferably with deep cankers producing abundant resin flow, especially those facing a vertical seepage moist cliff or adjacent to a brook, bog or small lake) have been fulfilled. Threats for the existence of these species are likely to be the same as for many other organisms that only live in mature, old or ancient sprucedominated forests. For example, in Finland such forests are endangered (NT to CR in Tonteri et al. 2008). Undoubtedly all three resinicolous species can be added to Tibell's (1992) list of
Chaenothecopsis species that have value as indicators of long forest continuity ( $C$. haematopus Tibell, C. viridialba (Kremp.) A.F.W.Schmidt, $C$. nana Tibell).

The disjunct range of all three species - the Pacific coast of North America and Europe seems peculiar. Since potential hosts and suitable habitats exist throughout the boreal zone, it is quite likely that some, if not all of them are or historically have been circumboreal species, which have not yet been reported from Asia or eastern North America. It seems less likely that these species would have originated in either of the two areas and then spread to the other by long range dispersal.

The presently known European distribution of the species, with populations both in the northern coniferous forests and in the montane 
forests in Spain and Switzerland, give reason to believe that these species have survived the last glacial period in the same refugial areas as their host trees Picea and Abies. The collections from Switzerland were made less than $70 \mathrm{~km}$ from a suggested refugium of Abies alba (Bennet et al. 1991) and the site in Baetic mountain system in Spain is within a refugium from the last glacial maximum that now hosts relict populations of Abies pinsapo (Alba-Sánchez et al. 2010, Martín et al. 2010). Taking into consideration the full range of all three species, it is logical to assume that these fungi may have been widespread in Europe during the early and middle Weichselian (110 000 - 34000 bp), when P. abies was more widely distributed and common in central and southeastern Europe (Ravazzi 2002). European amber fossils of resinicolous Chaenothecopsis species have shown that the morphology and ecology of these fungi have remained unchanged for at least tens of millions of years (Rikkinen \& Poinar 2000, Tuovila et al. unpubl.). Thus, the history of some populations in the relict forests of central and southern Europe might trace back to the Eocene, when montane coniferous in Europe may already have supported Abies and Tsuga species (Kvaček 2010).

The modern population of spruce in Northern Europe regenerated from refugial populations in the Russian Plain and there seems to have been no genetic exchange between these populations and the spruce populations that survived in southern and central Europe (Tollefsrud et al. 2008). Thus, it is logical to presume that also European populations of resinicolous Chaenothecopsis were able to overwinter in the Russian refugia. Through the ancestors of these populations they may also have been in direct contact with the fungi that are now found in western North America.

Acknowledgements: Jenny and Antti Wihuri foundation, Ella and Georg Ehrnroth foundation and Suomen Luonnonsuojelun Säätiö are thanked for funding. We thank Teppo Rämä (Finland) and Dr. Urs Gröner (Switzerland), who kindly sent us specimens. We also thank Heino Vänskä for helping with the Latin diagnosis and Marie Davey and Ernest Emmett for improving the English. Dr. Seppo Huhtinen (Turku) for valuable comments on many taxonomical details.

\section{References}

Alba-Sánchez, F., López-Sáez, J., Benito-de Pando, B., Linares, J., Nieto-Lugilde, D. \& López-Merino, L. 2010: Past and present potential distribution of the Iberian Abies species: a phytogeographic approach using fossil pollen data and species distribution models. - Diversity and Distributions 16: 214-228.

Bennett, K., Tzedakis, P. \& Willis, K. 1991: Quaternary refugia of North European trees. - Journal of Biogeography 18: 103-115.

Geiser, D., Gueidan, C., Miadlikowska, J., Lutzoni, F., Kauff, F., Hofstetter, V., Fraker, E., Schoch, C., Tibell, L., Untereiner, W. \& Aptroot, A. 2006: Eurotiomycetes: Eurotiomycetidae and Chaetothyriomycetidae. - Mycologia 98: 1053-1064.

Gudovicheva, A. \& Titov, A. 2007: Chaenothecopsis dolicocephala - new species of calicioid fungus for Europe. - Mikologia i Fitopatologia 41: 421-424.

Hålien, H. \& Tønsberg, T. 1996: Boreal regnskog i Norge - habitatet for trøndelagselementets lavarter. - Blyttia 54: 157-177.

Jääskeläinen, K., Pykälä, J., Rämä, H., Vitikainen, O., Haikonen, V., Högnabba, F., Lommi, S. \& Puolasmaa, A. 2010: Jäkälät - Lichens. In: Rassi, P., Hyvärinen, E., Juslén, A. \& Mannerkoski, I. (eds) 2010: The 2010 Red List of Finnish Species: 278-310. Ympäristöministeriö \& Suomen ympäristökeskus.

Kvaček, Z. 2010: Forest flora and vegetation of the early European Palaeogene - a review. - Bulletin of Geosciences 85: 63-76.

Martín, M., Alvarez, L. \& Martín L. 2010: Genetic diversity of Spanish fir (Abies pinsapo Boiss.) populations by means of megagametophyte storage proteins. - Annals of Forest Science 67: 603.

Ravazzi, C. 2002: Late Quaternary history of spruce in southern Europe. - Review of Palaeobotany and Palynology 120: 131-177.

Rikkinen, J. 1999: Two new species of resinicolous Chaenothecopsis (Mycocaliciaceae) from Western North America. - Bryologist 102: 366-369.

Rikkinen, J. 2003a: Calicioid lichens and fungi in the forests and woodlands of Western Oregon. - Acta Botanica Fennica 175: 1-41.

Rikkinen, J. 2003b: Chaenothecopsis nigripunctata, a remarkable new species of resinicolous Mycocaliciaceae from western North America. - Mycologia 95: 98-103.

Rikkinen, J. 2003c: New resinicolous ascomycetes from beaver scars in Western North America. - Annales Botanici Fennici 40: 443-450.

Rikkinen, J. \& Poinar, G. 2000: A new species of resinicolous Chaenothecopsis (Mycocaliciaceae, Ascomycota) from 20 million year old Bitterfeld amber, with remarks on the biology of resinicolous fungi. - Mycological Research 104: 7-15.

Schmidt, A. 1970: Anatomisch-taxonoische Untersuchungen an europäischen Asten der Flechtenfamilie Caliciaceae. - Mitteilungen aus dem Staatsinstitut für Allgemeine Botanik Hamburg 13: 111-166. 
Thor, G., Arup, U., Arvidsson, L., Hermansson, J., Hultengren, S., Jonsson, F. \& Karström, M. 2010: Lavar - Lichens. In: Rödlistade arter i Sverige 2010 - The 2010 Red List of Swedish Species: 285-300. Artdatabanken, Uppsala.

Tibell, L. 1987: Australasian Caliciales. - Acta Universitatis Upsaliensis. Symbolae Botanicae Upsalienses 27: $1-279$.

Tibell, L. 1992: Crustose lichens as indicators of forest continuity in boreal coniferous forests. - Nordic Journal of Botany 12: 427-450.

Tibell, L. \& Titov, A. 1995: Species of Chaenothecopsis and Mycocalicium (Caliciales) on exudate. - Bryologist 98: 550-560.

Tibell, L., \& Vinuesa, M. (2005). Chaenothecopsis in a molecular phylogeny based on nuclear rDNA ITS and LSU sequences. - Taxon 54: 427-442.

Titov, A. 1998: New and rare calicioid lichens and fungi from relict tertiary forests of Caucasus and the Crimea. - Folia Cryptogamica Estonica 32: 127-133.

Titov, A. 2006: Mikokalitsievye griby (poryadok Mycocaliciales) golarktiki [Mycocalicioid fungi (the order Mycocaliciales) of the Holarctic]. - KMK Scientific Press, Moscow. 295 pp.

Titov, A. \& Tibell, L. 1993: Chaenothecopsis in the Russian Far East. - Nordic Journal of Botany 13: 313329.
Titov, A. \& Tibell, L. 1999: Chaenothecopsis tristis, a rare resinicolous species of the Mycocaliciaceae. - Mycotaxon 70: 471-476.

Tollefsrud, M., Kissling, R. Gugerli, F., Johnsen, Ø., Skrøppa, T., Chedadi, R., Van Der Knaap, W., Lataàowa, M., Terhürne-Berson, R., Litt, T., Geburek, T., Brochmann, C. \& Sperisen, S. 2008: Genetic consequences of glacial survival and postglacial colonization in Norway spruce: combined analysis of mitochondrial DNA and fossil pollen. - Molecular Ecology 17: 4134-4150.

Tonteri, T., Ahlroth, P., Hokkanen, M., Lehtelä, M., Alanen, A., Hakalisto, S., Kuuluvainen, T., Soininen, T. \& Virkkala, R. 2008: Metsät - Forests. In: Raunio, A., Schulman, A. \& Kontula, T. (eds.) 2008: The assessment of threatened habitat types in Finland - Part 2: Habitat type descriptions: 261-334. Suomen ympäristökeskus, Helsinki.

Tuovila, H., Cobbinah, J. \& Rikkinen, J. 2011: Chaenothecopsis khayensis - a new resinicolous calicioid from tropical Africa. - Mycologia 103: 610-615.

Vainio, E. 1927: Lichenographica Fennica III. Coniocarpae. - Acta Societas pro Fauna et Flora Fennica 57: $1-138$. 